\title{
Occurrence of Beta-Lactamases Genes in Beta-Lactam Resistant Bacteria Isolated from Milk of Goats with Sub-Clinical Mastitis in Thika Sub-County, Kenya
}

\author{
Irene Mkavi Okoko ${ }^{1}$, John Kagira ${ }^{2 *}$, Daniel Kiboi ${ }^{3}$, and Naomi Maina ${ }^{1,3}$ \\ ${ }^{I}$ Department of Molecular Biology and Biotechnology, Pan-African University, Institute of Basic Sciences, Technology and Innovation, P.O. Box \\ 62000-00200, Nairobi, Kenya \\ ${ }^{2}$ Department of Animal Sciences, Jomo Kenyatta University of Agriculture and Technology, P.O. Box 62000-00200, Nairobi, Kenya \\ ${ }^{3}$ Department of Biochemistry, Jomo Kenyatta University of Agriculture and Technology, P.O. Box 62000-00200, Nairobi, Kenya \\ *Corresponding author's Email: jkagira@jkuat.ac.ke; (D)RCiD: 0000-0001-5513-2113
}

\begin{abstract}
For decades, beta-lactam antibiotics have played a critical role in the control of mastitis in animals. However, the emergence of beta-lactam-resistant bacteria poses a challenge to both human and veterinary medicine. In this regard, bacterial isolates from milk samples collected from dairy goats with sub-clinical mastitis from Thika Sub-county, Kenya, were used in the current study to interrogate the occurrence of beta-lactamases genes in bacterial isolates (Klebsiella pneumoniae, Staphylococcus aureus, and Acinetobacter spp., and Coagulase-negative Staphylococci) with known phenotypic resistance profiles to penicillin G, cephalexin, cefoxitin, and cefotaxime. Four target genes, $b l a_{\mathrm{TEM}}, b l a_{\mathrm{SHV}}, b l a_{\mathrm{CTX}}, b l a_{\mathrm{OXA}}$, and $b l a_{\mathrm{KPC}}$ were amplified using a polymerase chain reaction, and compared with Escherichia coli American Type Culture Collection 35218 and non-standard Klebsiella pneumonia positive controls. Out of the 46 samples, 44 samples $(95.7 \%)$ harbored bla $a_{\mathrm{TEM}}$ with two samples of the 44 bacterial isolates, also possessing the bla $a_{\mathrm{SHV}}$ gene. Only one isolate of Klebsiella pneumonia and Acinetobacter spp had a combination of $b l a_{\mathrm{TEM}}$ and $b l a_{\mathrm{SHV}}$. None of the bacteria had $b l a_{\mathrm{CTX}}, b l a_{\mathrm{OXA}}$, and $b l a_{\mathrm{KPC}}$ genes. The data indicated that sub-clinical mastitis in dairy goats in Thika Sub-county is associated with the bacteria carrying beta-lactamases genes, suggesting that the use of beta-lactam antibiotics for the treatment of sub-clinical mastitis may result in the treatment failure and potential transfer of the infectious bacteria to humans and other animals. The current study recommends the use of an alternative class of antibiotics for the management of beta-lactam-resistant bacteria.
\end{abstract}

Keywords: Bacteria, Beta-lactam resistance, Beta-lactamases, Sub-clinical mastitis

\section{INTRODUCTION}

Antimicrobial resistance (AMR) is a global health concern (Scarafile, 2016) that adversely impacts the world's economy, and causes high morbidities and mortalities (Hwang and Gums, 2016). It has been estimated that by 2050, annual global deaths associated with AMR would be 10 million (Kraker et al., 2016). Despite the lack of well-established surveillance systems (Tadesse et al., 2017), a few recent studies have shown a gradually increasing high prevalence in Africa (Ntirenganya et al., 2015; Ampaire et al., 2016), including Kenya (NRL, 2017). Of significant concerns are betalactamases conferring resistance to a wide range of beta-lactam antibiotics, including penicillins, first, second, and thirdgeneration cephalosporins as well as cephamycins (Shahid et al., 2011). The rapid emergence and spread of AMR have been accelerated by the excessive and unregulated use of antibiotics in rapidly expanding agricultural practices such as livestock rearing (Economou and Gousia, 2015).

The dairy industry faces several challenges, including diseases, such as mastitis, which is an infection of the mammary gland mostly by bacteria, and its treatment is through intramammary administration of antibiotics (Contreras et al., 2007). Beta-lactam class of antibiotics is among the antibiotics widely used in the management of intramammary infections in dairy animals (Oliver and Murinda, 2012). Beta-lactamase enzymes cause the hydrolysis of the amide bond of the beta-lactam ring hence inactivating the beta-lactam antibiotics causing bacterial resistance (Shahid et al., 2011). Additionally, the beta-lactamase genes are encoded within the plasmids and can be transferred within and between bacterial pathogens (Bora et al., 2014). Beta-lactamases can be either extended-spectrum beta-lactamases (ESBLs) or non-ESBLs depending on the mutations of the parent enzymes (Bora et al., 2014). There are several types of betalactamases; however, Temoniera (TEM), Sulfhydryl variant (SHV), and Cefotaxime-Munich (CTX-M) -types are the predominant ones, especially in Gram-negative bacteria (Bora et al., 2014). The prevalence of beta-lactamases varies in different regions (Shah et al., 2004) with these enzymes becoming widely distributed in animals that are reared for food (Dahmen et al., 2013). However, a specific bacterial isolate and presence of beta-lactamase genes in dairy animals with mastitis remains poorly understood, and highly controversial with only a few studies reporting beta-lactamases bacteria 
in cows with mastitis (Dahmen et al., 2013; Su et al., 2016; Das et al., 2017; Younis et al., 2017). Studies focusing on dairy goats have lagged behind, despite the fact that dairy goat farming is a potential source and spreader of bacteria with beta-lactam resistance genes.

In goats, bacteria within the family Enterobacteriaceae and genera Staphylococcus are frequently associated with sub-clinical mastitis (Contreras et al., 2007). These bacteria cause diseases that result in major economic losses, such as high treatment cost, loss of production, reduced milk quality, and quantity (Contreras et al., 2007; Oliver and Murinda, 2012; Gelasakis et al., 2016). In Kenya, the prevalence of sub-clinical mastitis in goats vary in different geographical regions, for instance, studies have recorded more than $50 \%$ prevalence of sub-clinical mastitis in Thika Sub-county (Mahlangu et al., 2018); however, the bacterial isolates and the presence of beta-lactamases genes remains poorly understood. Our recent study documented the phenotypic resistance profiles of beta-lactam antibiotics in bacteria causing sub-clinical mastitis in goats in Thika Sub-county, Kenya (Okoko et al., 2020). As a follow-up study, the molecular architecture of bacterial isolates from milk samples of goats with sub-clinical mastitis was interrogated. The presence of beta-lactamases genes in the bacteria causing sub-clinical mastitis in goats was reported suggesting a growing challenge in the treatment of the disease in animals, and the high potential of goat milk as a transmission vehicle of resistance genes to humans.

\section{MATERIALS AND METHODS}

\section{Study site description}

The study was conducted in Thika Sub-county in Kiambu County, Kenya. The area lies $42 \mathrm{~km}$ northeast of Nairobi, the capital city of Kenya (Okoko et al., 2020). The area experiences an estimated annual average temperature of $19.8^{\circ} \mathrm{C}$ and bimodal rainfall that ranges from $500 \mathrm{~mm}$ to $1300 \mathrm{~mm}$. Farmers in the locality practice intensive dairy goat farming with approximately $30 \%$ of them depending on the enterprise as a source of livelihood (Okoko et al., 2020).

\section{Sample size determination and sample selection}

To obtain the sample size, the study used an estimated overall mean prevalence of antibiotic resistance of $40 \%$ in Thika Sub-county obtained by Mahlangu et al. (2018). Using this prevalence, approximately 46 bacterial isolates were randomly selected from 114 beta-lactam resistant bacterial isolates obtained from a larger study conducted in Thika Subcounty (Okoko et al., 2020). The phenotypic characteristics of 46 bacterial isolates selected for the molecular analysis are shown in Table 1. The results of the study were stratified according to the origin of the goats in different wards within Thika Sub-county. The wards included Hospital, Kamenu, Gatuanyaga, Ngoliba, and Township.

\section{DNA extraction}

The DNA was extracted by the heating method as described by Dilhari et al. (2017) with modifications. Briefly, cells from $1.5 \mathrm{ml}$ of beta-lactam resistant bacterial samples, stored in Tryptic soy broth with $20 \%$ glycerol, were collected by centrifuging the samples at $17,310 \mathrm{X} \mathrm{g}$ (or $26000 \mathrm{rpm}$ ) for 5 minutes. The supernatant was discarded while the pellet re-suspended in $200 \mu \mathrm{l}$ sterile distilled water. The cells were incubated in a thermal cycler at $95^{\circ} \mathrm{C}$ for 10 minutes for lysis. Centrifugation was done at 17,310 X g (or $26000 \mathrm{rpm}$ ) for 5 minutes to get rid of the cellular debris. The supernatant was then used as a source of DNA template for amplification. The supernatant was stored at $4{ }^{\circ} \mathrm{C}$ or $80^{\circ} \mathrm{C}$ for short-term and long-term storage, respectively (Kim et al., 2012).

\section{Primer properties}

Following recommendations by Bustin and Huggett (2017), sequences for bla $a_{T E M}$, bla $_{S H V}$, bla $_{C T X}$, bla $_{O X A}$, and bla $_{K P C}$ genes were obtained from Ensembl database (http://bacteria.ensembl.org/index.html) from where the primer sequence was derived using Primer3Plus software (http://www.bioinformatics.nl/cgi-bin/primer3plus/primer3plus.cgi, Lu et al., 2017). The properties of the selected primers were then tested using OligoCalc Software (http://biotools.nubic.northwestern.edu/OligoCalc.html) and blasted in https://blast.ncbi.nlm.nih.gov/Blast.cgi (Bustin and Huggett, 2017; Lu et al., 2017). Five sets of primers were used for amplifying $b l a_{\mathrm{TEM}}, b l a_{\mathrm{CTX}-\mathrm{M}}, b l a_{\mathrm{SHV}}, b l a_{\mathrm{OXA}-1,}$ and bla $_{\mathrm{KPC}}$ genes (Table 2).

\section{Polymerase chain reaction for amplification of bla $_{\mathrm{TEM}}$, bla $_{\mathrm{CTX}-\mathrm{M}}$, bla $_{\mathrm{SHV}}$, bla $_{\mathrm{OXA}-1,}$ and bla $_{\mathrm{KPC}}$ genes}

Amplification was performed in $10 \mu \mathrm{l}$ reaction mixture containing $2 \mu \mathrm{l}$ of $5 \mathrm{X}$ FIREPol Master Mix containing FIREPol DNA polymerase (Solis BioDyne, Tartu, Estonia), $0.5 \mu 1$ of $10 \mathrm{pmol} / \mu 1$ of the primers (Macrogen, Europe), and $4 \mu \mathrm{l}$ of template DNA as described by Saisi et al. (2019) with modifications. The polymerase chain reaction (PCR) water was used to top up the reaction volume to $10 \mu$ l. No template negative control (with no DNA) and two positive controls containing DNA of the control strains were included. Both Escherichia coli American Type Culture Collection (ATCC) 35218 and non-standard Klebsiella pneumoniae that harbor $b_{l} a_{\mathrm{TEM}}$ and $b l a_{\mathrm{SHV}}$, respectively, were used as the 
positive controls. Multiplex PCR for $b l a_{\mathrm{TEM}}$ and $b l a_{\mathrm{SHV}}$ primers was done according to Monstein et al. (2007) with modifications. The following thermal cycling conditions were used: Initial denaturation at $95^{\circ} \mathrm{C}$ for 10 minutes followed by 30 cycles of denaturation at $95^{\circ} \mathrm{C}$ for 30 seconds, annealing at $60^{\circ} \mathrm{C}$ for 30 seconds, extension at $72^{\circ} \mathrm{C}$ for 1 minute and 30 seconds, and the final extension at $72^{\circ} \mathrm{C}$ for 10 minutes (Monstein et al., 2007). The primer properties of the other bla genes used in the study $\left(b l a_{C X T-M}, b l a_{O X A}\right.$, and $\left.b l a_{K P C}\right)$ are shown in Table 2. Gel electrophoresis was conducted according to Saisi et al. (2019) with minor modifications. The PCR products were analyzed using $1 \%$ agarose gel in $1 \mathrm{X}$ Tris-borate- Ethylenediaminetetraacetic acid (EDTA) buffer. 1Kb Plus GeneRuler DNA Ladder (Thermo Scientific) was run together with the samples. Then, 50 Voltage was applied during the electrophoresis, and run for 45 minutes. In place of ethidium bromide, the gels were stained with TruGel nucleic acid staining dye, and photographed under ultraviolet (UV) light trans-illuminator (Saisi et al., 2019).

Table 1. The phenotypic characteristics of beta-lactam resistant bacteria isolated from milk of goats with sub-clinical mastitis in Thika Sub-county, Kenya.

\begin{tabular}{|c|c|c|c|c|c|c|c|c|}
\hline \multirow[b]{2}{*}{ Bacterial isolate } & \multirow{2}{*}{$\begin{array}{l}\text { Source (Goat } \\
\text { ID) }\end{array}$} & \multirow{2}{*}{$\begin{array}{c}\text { Total } \\
\text { number of } \\
\text { resistant } \\
\text { isolates } \\
\end{array}$} & \multicolumn{6}{|c|}{$\%$ proportion of resistant bacterial isolates to beta-lactam antibiotics } \\
\hline & & & $\mathbf{P}$ & $\mathbf{P}, \mathbf{C N}$ & $P$, CN, FOX & $\begin{array}{c}\text { P, CN, } \\
\text { FOX, CTX }\end{array}$ & P, CTX & $\begin{array}{c}\text { P, CN, } \\
\text { CTX }\end{array}$ \\
\hline $\begin{array}{l}\text { Klebsiella } \\
\text { pneumoniae }\end{array}$ & $\begin{array}{c}32,36,53,55 \\
64,72,73,77 \\
104,107\end{array}$ & $10(21.7 \%)$ & 0 & $1(10 \%)$ & 0 & $4(40 \%)$ & $1(10 \%)$ & $4(40 \%)$ \\
\hline $\begin{array}{l}\text { Staphylococcus } \\
\text { aureus }\end{array}$ & $\begin{array}{c}5,7,9,24,31 \\
54,75,109\end{array}$ & $8(17.4 \%)$ & $4(50 \%)$ & 0 & $1(12.5 \%)$ & $2(25 \%)$ & 0 & $1(12.5 \%)$ \\
\hline Acinetobacter spp. & $\begin{array}{l}31,32,42,43 \\
46,77,79,97\end{array}$ & $8(17.4 \%)$ & 0 & $1(12.5 \%)$ & 0 & $6(75 \%)$ & $1(12.5 \%)$ & 0 \\
\hline $\begin{array}{l}\text { Coagulase negative } \\
\text { Staphylococci }\end{array}$ & $\begin{array}{c}8,43,44,80 \\
109\end{array}$ & $5(10.9 \%)$ & 0 & 0 & 0 & $4(80 \%)$ & $1(20 \%)$ & 0 \\
\hline Escherichia coli & $22,69,94$ & $3(6.5 \%)$ & 0 & $1(33.3 \%)$ & 0 & 0 & 0 & $2(66.7 \%)$ \\
\hline $\begin{array}{l}\text { Enterobacter } \\
\text { intermedius }\end{array}$ & 13,62 & $2(4.3 \%)$ & 0 & 0 & 0 & 0 & 0 & $2(100 \%)$ \\
\hline Proteus vulgaris & 21,25 & $2(4.3 \%)$ & 0 & $2(100 \%)$ & 0 & 0 & 0 & 0 \\
\hline Citrobacter diversus & 45,106 & $2(4.3 \%)$ & 0 & 0 & 0 & 0 & 0 & $2(100 \%)$ \\
\hline Yersinia spp., & 80,102 & $2(4.3 \%)$ & 0 & 0 & 0 & 0 & 0 & $2(100 \%)$ \\
\hline Serratia marcescens & 47 & $1(2.2 \%)$ & 0 & 0 & 0 & 0 & 0 & $1(100 \%)$ \\
\hline Citrobacter freundii & 56 & $1(2.2 \%)$ & 0 & 0 & 0 & $1(100 \%)$ & 0 & 0 \\
\hline Klebsiella oxytoca & 78 & $1(2.2 \%)$ & 0 & 0 & 0 & 0 & 0 & $1(100 \%)$ \\
\hline Serratia fonticola & 108 & $1(2.2 \%)$ & 0 & 0 & 0 & $1(100 \%)$ & 0 & 0 \\
\hline Total & & $46(100 \%)$ & $4(8.7 \%)$ & $5(10.9 \%)$ & $1(2.2 \%)$ & $18(39.1 \%)$ & $3(6.5 \%)$ & $15(32.6 \%)$ \\
\hline
\end{tabular}

P: Penicillin G, CN: Cephalexin, FOX: Cefoxitin, CTX: Cefotaxime.

Table 2. Properties of the oligonucleotide primers used for amplification of $b l a_{\mathrm{TEM}}, b l a_{\mathrm{CTX}-\mathrm{M}}, b l a_{\mathrm{SHV}}, b l a_{\mathrm{OXA}-1}$ and $b l a_{\mathrm{KPC}}$ genes highlighting the expected sizes of the product, the melting temperature and source reference

\begin{tabular}{|c|c|c|c|c|}
\hline Primer & Sequence & $\begin{array}{c}\text { Melting } \\
\text { temperature (Tm) }\end{array}$ & $\begin{array}{l}\text { Expected amplicon } \\
\text { size, base pair (bp) }\end{array}$ & Reference \\
\hline$b l a_{\mathrm{TEM}}$ & $\begin{array}{l}\text { F_TCGCCGCATACACTATTCTCAGAATGA } \\
\text { R_ACGCTCACCGGCTCCAGATTTAT }\end{array}$ & $65^{\circ} \mathrm{C}$ & $445 \mathrm{bp}$ & (Monstein et al., 2007) \\
\hline$b^{b l a} a_{\mathrm{SHV}}$ & $\begin{array}{l}\text { F_ATGCGTTATATTCGCCTGTG } \\
\text { R_TGCTTTGTTATTCGGGCCAA }\end{array}$ & $56^{\circ} \mathrm{C}$ & $723 b p$ & (Monstein et al., 2007) \\
\hline$b^{b l a} a_{\text {СтХ-м }}$ & $\begin{array}{l}\text { F_GCCATGAATAAGCTGATTGC } \\
\text { R_CTTTACCCAGCGTCAGATTTT }\end{array}$ & $57^{\circ} \mathrm{C}$ & $193 \mathrm{bp}$ & Present study \\
\hline$b l a_{\mathrm{OXA}}$ & $\begin{array}{l}\text { F_AATCCGAATCTTCGCGATACT } \\
\text { R_GGTATCTTG AATGTCGATGC }\end{array}$ & $57^{\circ} \mathrm{C}$ & $225 \mathrm{bp}$ & Present study \\
\hline$b l a_{\mathrm{KPC}}$ & $\begin{array}{l}\text { F_ATGTCACTGTATCGCCGTCT } \\
\text { R_TTACTGCCCGTTGACGCCC }\end{array}$ & $60^{\circ} \mathrm{C}$ & $882 b p$ & (Ribeiro et al., 2016) \\
\hline
\end{tabular}

Keys: bla TЕм $_{\text {: }}$ Temoniera beta lactamase, bla $_{\mathrm{CTX- \textrm {M }}}$ : Cefotaxime-Munich beta lactamase, bla $a_{\mathrm{SHV}}$ : Sulfhydryl variant beta lactamase, bla $a_{\mathrm{OXA}}$ : Oxacillin beta lactamase, bla $a_{\mathrm{KPC}}$ : Klebsiella pneumoniae carbapenemase.

\section{RESULTS}

On amplification of $b a_{\mathrm{TEM}}$, a fragment of size $445 \mathrm{bp}$ (Plate 1), as expected, on the 46 isolates was amplified. Out of 46 bacterial isolates, $44(95.7 \%)$ were positive for beta-lactamase genes (Table 3). Additionally, on amplification of bla $a_{\mathrm{SHV}}$, a fragment of size $753 \mathrm{bp}$ (Plate1) was amplified as expected. Interestingly, bla $a_{\mathrm{SHV}}$ gene occurred only in combination with $b l a_{\mathrm{TEM}}$. Out of the 44 bacterial isolates with $b l a_{\mathrm{TEM}}, 2(4.5 \%)$ were positive for $b l a_{\mathrm{SHV}}$ (Table 3 ). However, on the amplification of $b l a_{\mathrm{CTX}-\mathrm{M}}, b l a_{\mathrm{OXA}}$, and $b l a_{\mathrm{KPC}}$ genes, with expected band sizes of $193 \mathrm{bp}, 225 \mathrm{bp}$, and $882 \mathrm{bp}$ respectively, no fragment was obtained from the 46 bacterial isolates. The results were grouped according to different beta-lactam- 
resistance patterns shown by the bacterial isolates. This was done to determine the distribution of bla genes within various categories of resistance patterns shown by the bacteria. It was noted that out of the 46 bacterial isolates, 17 (37\%) were phenotypically cross-resistant to penicillin $\mathrm{G}$, cephalexin, cefoxitin, and cefotaxime antibiotics, harbored the $b l a_{T E M}$ gene. Additionally, all the bacterial isolates that were phenotypically resistant to cefotaxime antibiotics did not harbor the targeted $b l a_{\mathrm{CTX}-\mathrm{M}}$ gene. It was also noticed that $b l a_{\mathrm{TEM}}$ and $b l a_{\mathrm{SHV}}$ were present in all the isolates that were resistant to cefoxitin antibiotic (Table 4).

The results were also stratified according to different wards within Thika Sub-county. This was performed to determine the distribution of bla genes within Thika Sub-county. Out of 44 bacterial isolates with bla $a_{\text {TEM }}$ genes, 23/44 $(52.3 \%)$ were from goats in the hospital ward, 8/44 (18.2\%) from Kamenu ward, 7/44 (15.9\%) from Gatuanyaga ward, $3 / 44(6.8 \%)$ from Ngoliba ward, and 3/44 (6.8\%) from Township ward. Interestingly, all of the bacterial isolates with $b l a_{\mathrm{SHV}}$ gene were from goats in the Gatuanyaga ward.

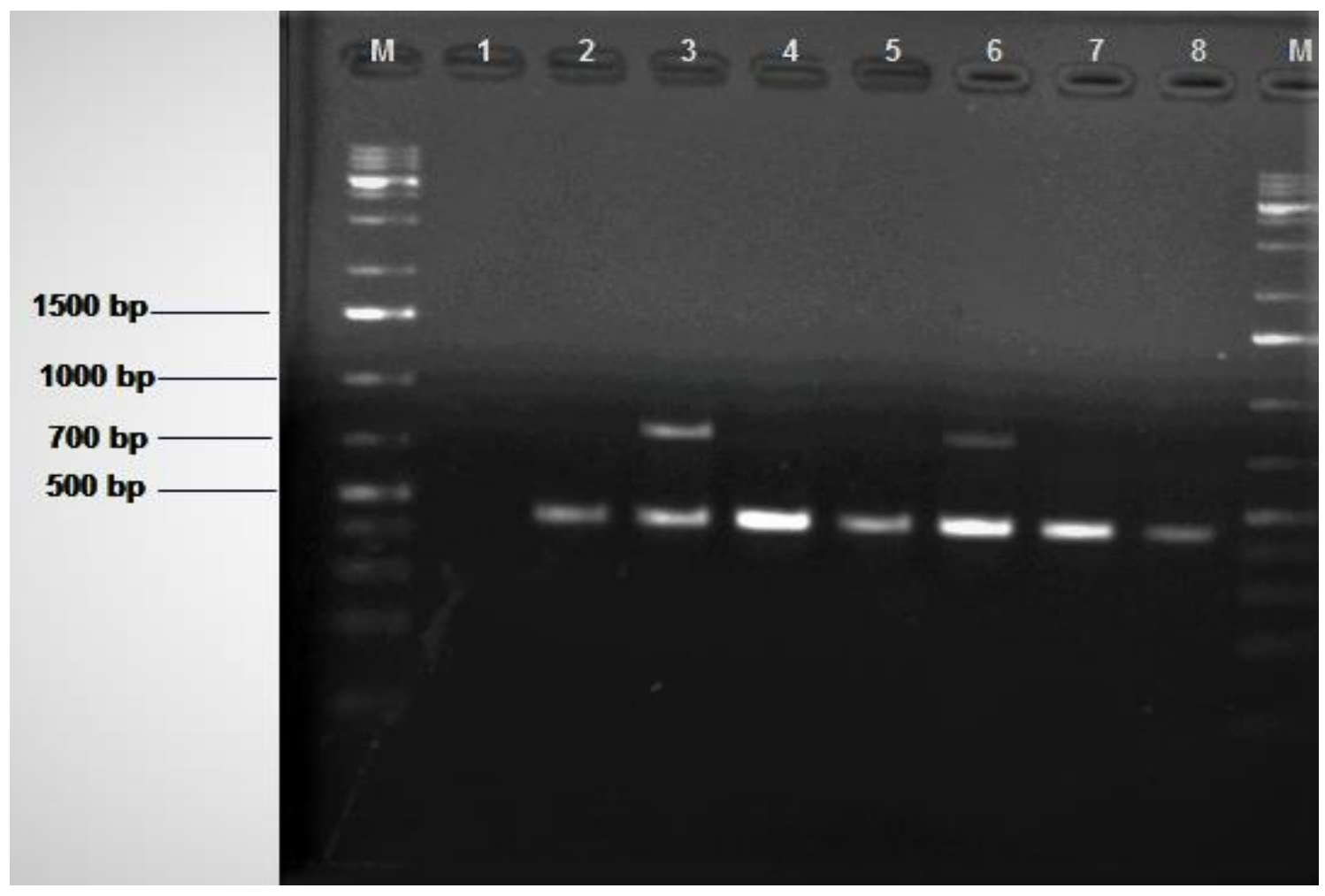

Plate 1. A representative $1 \%$ agarose gel image of a multiplex PCR for $b l a_{T E M}$ and $b l a_{S H V}$ in bacterial isolates that were cross-resistant to penicillin G, cephalexin, cefoxitin and cefotaxime beta lactam antibiotics. Lane M: $1 \mathrm{kB}$ Plus Generuler DNA Ladder; Lane 1: No template control; Lane 2-3: positive control for $b l a_{\mathrm{TEM}}$ and bla $_{\mathrm{SHV}}$ with sizes $445 \mathrm{bp}$ and $753 \mathrm{bp}$ respectively as indicated in table 1; Lane 4-8: bla genes from the samples.

Table 3. Occurrence of bla genes in resistant bacterial isolates from milk samples obtained from goats with sub-clinical mastitis in Thika sub-county, Kenya.

\begin{tabular}{|c|c|c|c|c|c|c|}
\hline \multirow{2}{*}{ Bacterial isolate } & \multirow{2}{*}{$\begin{array}{l}\text { Number of } \\
\text { isolates }\end{array}$} & \multicolumn{3}{|c|}{ Proportions (\%) } & \multirow[b]{2}{*}{ bla $_{\mathrm{CTX-M}}$} & \multirow[b]{2}{*}{$b l a_{\mathrm{KPC}}$} \\
\hline & & $b l a_{\mathrm{TEM}}$ & $b l a_{\mathrm{TEM}}+b l a_{\mathrm{SHV}}$ & $b l a_{\text {OXA }}$ & & \\
\hline Klebsiella pneumonia & 10 & $9(90 \%)$ & $1(10 \%)$ & - & - & - \\
\hline Staphylococcus aureus & 8 & $7(87.5 \%)$ & - & - & - & - \\
\hline Acinetobacter spp. & 8 & $7(87.5 \%)$ & $1(12.5 \%)$ & - & - & - \\
\hline CNS & 5 & $5(100 \%)$ & - & - & - & - \\
\hline Escherichia coli & 3 & $3(100 \%)$ & - & - & - & - \\
\hline Enterobacter intermedius & 2 & $2(100 \%)$ & - & - & - & - \\
\hline Proteus vulgaris & 2 & $2(100 \%)$ & - & - & - & - \\
\hline Citrobacter diversus & 2 & $1(50 \%)$ & - & - & - & - \\
\hline Yersinia spp. & 2 & $2(100 \%)$ & - & - & - & - \\
\hline Serratia marcescens & 1 & $1(100 \%)$ & - & - & - & - \\
\hline Serratia fonticola & 1 & $1(100 \%)$ & - & - & - & - \\
\hline Citrobacter freundii & 1 & $1(100 \%)$ & - & - & - & - \\
\hline Klebsiella oxytoca & 1 & $1(100 \%)$ & - & - & - & - \\
\hline TOTAL & 46 & $42(91.3 \%)$ & $2(4.3 \%)$ & & & \\
\hline
\end{tabular}

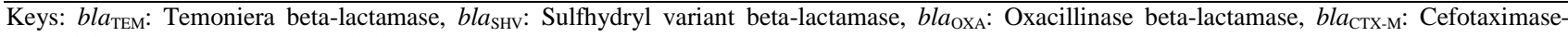
Munich beta-lactamase, bla $a_{\mathrm{KPC}}$ : Klebsiella pneumoniae Carbapenemase, CNS: Coagulase- Negative Staphylococcus, spp.: species. 
Table 4. Distribution of bla genes within different categories of beta-lactam-resistance patterns shown by bacteria isolated from milk samples of goats with sub-clinical in Thika sub-county, Kenya.

\begin{tabular}{|c|c|c|c|c|c|c|}
\hline Beta-lactam antibiotics & $\begin{array}{c}\text { Number of } \\
\text { resistant bacterial } \\
\text { isolates }\end{array}$ & $\begin{array}{c}\text { proportion of } \\
\operatorname{bla}_{\mathrm{TEM}}(\%)\end{array}$ & $\begin{array}{c}\text { proportion of } \\
\text { bla }_{\mathrm{TEM}} \text { and } \\
\text { bla }_{\mathrm{SHV}}(\%)\end{array}$ & $\begin{array}{c}\text { proportion } \\
\text { of } b l a_{\text {OXA }}(\%)\end{array}$ & $\begin{array}{c}\text { proportion of } \\
\operatorname{bla}_{\text {СТХ-М }}(\%)\end{array}$ & $\begin{array}{c}\text { proportion of } \\
\text { bla }_{\mathrm{KPC}}(\%)\end{array}$ \\
\hline $\mathrm{P}$ & $4(8.7 \%)$ & $3(6.5 \%)$ & 0 & 0 & 0 & 0 \\
\hline $\mathrm{P}, \mathrm{CN}$ & $5(10.9 \%)$ & $4(8.7 \%)$ & $1(2.2 \%)$ & 0 & 0 & 0 \\
\hline $\mathrm{P}, \mathrm{CN}, \mathrm{FOX}$ & $1(2.2 \%)$ & $1(2.2 \%)$ & 0 & 0 & 0 & 0 \\
\hline P, CN, FOX, CTX & $18(39.1 \%)$ & $17(37 \%)$ & $1(2.2 \%)$ & 0 & 0 & 0 \\
\hline P, CTX & $3(6.5 \%)$ & $3(6.5 \%)$ & 0 & 0 & 0 & 0 \\
\hline $\mathrm{P}, \mathrm{CN}, \mathrm{CTX}$ & $15(32.6 \%)$ & $14(30.4 \%)$ & 0 & 0 & 0 & 0 \\
\hline Total & $46(100 \%)$ & $42(91.3 \%)$ & $2(4.3 \%)$ & 0 & 0 & 0 \\
\hline
\end{tabular}

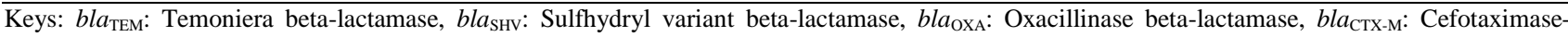
Munich beta-lactamase, bla $a_{\mathrm{KPC}}$ : Klebsiella pneumoniae Carbapenemase, CNS: Coagulase- Negative Staphylococcus, spp.: species, P: Penicillin G, CN: Cephalexin, FOX: Cefoxitin, CTX: Cefotaxime

\section{DISCUSSION}

Sub-clinical mastitis is the major cause of economic losses in dairy farming (Das et al., 2017). With the extensive use of beta-lactam antibiotics for the treatment of this disease, dairy goat represents a potential source of transmission of betalactam resistant genes (Das et al., 2017). In Kenya, beta-lactam (penicillin and cephalosporins) antibiotics are among the most used antibiotics for therapeutics and prophylactic purposes in animals including goats (Mitema et al., 2002). In the current study, the presence of beta-lactamase genes in bacteria associated with sub-clinical mastitis in goats was reported in Thika Sub-county. The bacterial isolates used in the present study were resistant to penicillin G, cephalexin, cefoxitin, and cefotaxime (Okoko et al., 2020).

Using PCR in the current study, it was found that bla $_{T E M}$ were the most common beta-lactamase genes $(95.7 \%)$ followed by bla $a_{S H V}$ that occurred in combination with $b l a_{T E M}$. The majority of ESBLs belong to Ambler's Class A, and among them are variants of the families TEM and SHV beta-lactamase (Bogaerts et al., 2016). The distribution of betalactamase genes varies widely with different studies reporting a varying prevalence of these genes. Beta lactamases have been well documented in studies on humans, environment, and food-producing animals (Maina et al., 2017). However, their distribution in the milk of goats with sub-clinical mastitis is not well known. Similar to the current study, a high occurrence of $b l a_{T E M}$ has been reported in the bacteria associated with bovine mastitis, for instance in Egypt (Younis et al., 2017) and Taiwan (Su et al., 2016). Contrary to the present study, a high occurrence of $b l a_{C T X-\mathrm{M}}$ followed by bla $a_{T E M}$ was reported in cows with sub-clinical mastitis in India (Das et al., 2017) and China (Ali et al., 2016). This difference shows that the prevalence of beta-lactamase genes varies from one geographical location to the other (Bajpai et al., 2017). This could be most likely due to the distribution pattern of beta lactamases in different geographical areas (Zaniani et al., 2012), study designs (Akpaka and Swanston, 2008), and sample sizes (Raut et al., 2015).

In the present study, $4.3 \%$ of the bacterial isolates had a double combination of SHV/TEM beta-lactamases. The occurrence of more than one beta-lactamase in one bacterial isolate has been reported in humans. For instance, in Kenya, a double combination of CTX-M/TEM and CTX-M/SHV and a triple combination of CTX-M/SHV/TEM was noted by Saisi et al. (2019) from diarrhea stool samples from children. Mshana et al. (2013) reported a combination of CTXM/TEM, SHV/CTX-M, and CTX-M alone in neonatal sepsis in Tanzania. According to Diagbouga et al. (2016), in Togo, a triple combination of TEM/SHV/CTX-M, and double combinations of SHV/CTX-M, TEM/CTX-M, TEM/SHV, and TEM alone has been reported from various pathological specimens in humans.

The TEM and SHV beta-lactamases are mostly reported in members of the family Enterobacteriaceae, including Klebsiella spp., Escherichia coli, Yersinia spp. Serratia spp., Citrobacter spp., Enterobacter spp. However, recently, beta-lactamases have been reported in other non-Enterobacteriaceae species (Alyamani et al., 2015). For instance, similar

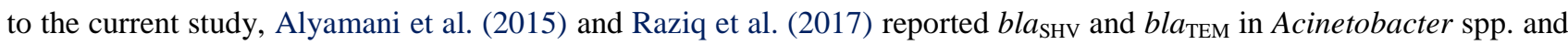
Staphylococcus aureus from humans, respectively.

In the current study, it was found that no bacteria had $b l a_{\mathrm{CTX}-\mathrm{M}}, b l a_{\mathrm{OXA}}$, and $b l a_{\mathrm{KPC}}$ genes. The absence of these genes was not definitive, since no positive control was available for them. However, negative genotypic results do not necessarily mean their absence in those resistant bacteria. This could be due to variants/ mutants of these enzymes that could not be targeted by the primers used in the present study. Negative genotypic results can also mean the presence of other families of beta-lactamases, such as ampicillin $\mathrm{C}$ (AmpC) beta-lactamase, that were not targeted in this study. Another possibility is the presence of other mechanisms of resistance to beta-lactams, apart from beta-lactamases (Maina et al., 2017).

The high prevalence of $b l a_{\mathrm{TEM}}$ in bacteria isolated from goat milk with sub-clinical mastitis is a public concern, especially since these enzymes are encoded within the bacterial plasmids, and can be transferred among and within bacterial species (Bora et al., 2014). This exchange of resistant genetic material among bacteria by horizontal transfer can occur in the goats' mammary glands (Rainard et al., 2018). This would result in a high diversity of mastitis- 
associated bacteria (Rainard et al., 2018), which can severely impact the dairy industry due to the complications in treating the resulting infections.

Additionally, these resistant genes encoding beta-lactamases have also been widely reported in human samples. For instance, beta-lactamases were isolated from human urinary isolates in Central India (Bajpai et al., 2017), from pediatric samples in Lebanon (Hijazi et al., 2016), human blood samples in Mali (Sangare et al., 2017), and stool samples in Kenya (Saisi et al., 2019). The spread from animals can occur mainly through the food chain, including consumption of raw milk (Diab et al., 2017). Recent reports indicate that the ability of beta-lactamase genes to be spread within and among bacterial species contributes to the increasing resistance to beta-lactam antibiotics worldwide (Li et al., 2007; Shaikh et al., 2015; Ur Rahman et al., 2018).

\section{CONCLUSION}

The present study indicated the emerging trend in antibiotic resistance bacteria associated with sub-clinical mastitis in goats. High occurrence of plasmid-mediated bla $_{\mathrm{TEM}}$ is a potential risk, as these resistant genes can be transmitted to other non-resistant bacteria making the beta-lactam antibiotics ineffective in treating the bacterial infections. Therefore, stringent measures, such as good animal husbandry and milking practices, should be adopted to control their possible spread to humans and other animals.

\section{Acknowledgments}

The current research was financially supported by the Institute of Basic Sciences, Technology and Innovation, PanAfrican University (PAUSTI), and Jomo Kenyatta University of Agriculture and Technology (JKUAT). The Grand Challenges Africa program (GCA/AMR/rnd2/079) also financially supported the work. Grand Challenges Africa is a program of the African Academy of Sciences (AAS) implemented through the Alliance for Accelerating Excellence in Science in Africa (AESA) platform, an initiative of the AAS and the African Union Development Agency (AUDANEPAD). Grand Challenges Africa is supported by the Bill and Melinda Gates Foundation (BMGF) and The AAS and partners.

\section{DECLARATIONS}

\section{Ethical approval}

Since the study did not utilize any invasive procedure, no ethical approval was required.

\section{Competing interests}

The authors declare no competing financial or personal interest.

\section{Authors' contributions}

Irene Mkavi Okoko, John Kagira, and Naomi Maina were involved in conceptualizing the research idea. Irene Mkavi Okoko and John Kagira planned the study design. Irene Mkavi Okoko performed laboratory work and interpretation of results. John Kagira and Daniel Kiboi provided laboratory guidance. Irene Mkavi Okoko drafted the manuscript. John Kagira, Daniel Kiboi, and Naomi Maina corrected the manuscript. All the authors read and approved the final manuscript.

\section{Data availability}

The raw data used to support the findings of this study are available at the corresponding author upon request.

\section{Consent to publish}

All authors agreed to publish the manuscript.

\section{REFERENCES}

Akpaka PE, and Swanston WH (2008). Phenotypic detection and occurrence of extended-spectrum beta-lactamases in clinical isolates of Klebsiella pneumoniae and Escherichia coli at a tertiary hospital in Trinidad \& Tobago. The Brazilian Journal of Infectious Diseases: An Official Publication of the Brazilian Society of Infectious Diseases, 12(6): 516-520. DOI: https://www.doi.org/10.1590/s1413-86702008000600014

Ali T, Ur Rahman S, Zhang L, Shahid M, Zhang S, Liu G, Gao J, and Han B (2016). ESBL-producing Escherichia coli from cows suffering mastitis in China contain clinical class 1 Integrons with CTX-M linked to ISCR1. Frontiers in Microbiology, 7: Article number: 1931. DOI: https://www.doi.org/10.3389/fmicb.2016.01931

Alyamani EJ, Khiyami MA, Booq RY, Alnafjan BM, Altammami MA, and Bahwerth FS (2015). Molecular characterization of extended-spectrum beta-lactamases (ESBLs) produced by clinical isolates of Acinetobacter baumannii in Saudi Arabia. Annals of Clinical Microbiology and Antimicrobials, 14(1): Article number: 38. DOI: https://www.doi.org/10.1186/s12941-015-0098-9 
Ampaire L, Muhindo A, Orikiriza P, Mwanga-Amumpaire J, Bebell L, and Boum Y (2016). A review of antimicrobial resistance in East Africa. African Journal of Laboratory Medicine, 5(1): Article number: 432. DOI: https://www.doi.org/10.4102/ajlm.v5i1.432

Bajpai T, Pandey M, Varma M, and Bhatambare GS (2017). Prevalence of TEM, SHV, and CTX-M Beta-Lactamase genes in the urinary isolates of a tertiary care hospital. Avicenna Journal of Medicine, 7(1): 12-16. DOI: https://www.doi.org/10.4103/2231-0770.197508

Bogaerts P, Cuzon G, Evrard S, Hoebeke M, Naas T, and Glupczynski Y (2016). Evaluation of a DNA microarray for rapid detection of the most prevalent extended-spectrum $\beta$-lactamases, plasmid-mediated cephalosporinases and carbapenemases in Enterobacteriaceae, Pseudomonas and Acinetobacter. International Journal of Antimicrobial Agents, 48(2): 189-193. DOI: https://www.doi.org/10.1016/j.ijantimicag.2016.05.006

Bora A, Hazarika NK, Shukla SK, Prasad KN, Sarma JB, and Ahmed G (2014). Prevalence of blaTEM, blaSHV and blaCTX-M genes in clinical isolates of Escherichia coli and Klebsiella pneumoniae from Northeast India. Indian Journal of Pathology and Microbiology, 57(2): 249-254. DOI: https://www.doi.org/10.4103/0377-4929.134698

Bustin S, and Huggett J (2017). QPCR primer design revisited. Biomolecular Detection and Quantification, 14: 19-28. DOI: https://www.doi.org/10.1016/j.bdq.2017.11.001

Contreras A, Sierra D, Sánchez A, Corrales JC, Marco JC, Paape MJ, and Gonzalo C (2007). Mastitis in small ruminants. Small Ruminant Research, 68: 145-153. DOI: https://www.doi.org/10.1016/j.smallrumres.2006.09.011

Dahmen S, Métayer V, Gay E, Madec JY, and Haenni M (2013). Characterization of extended-spectrum beta-lactamase (ESBL)-carrying plasmids and clones of Enterobacteriaceae causing cattle mastitis in France. Veterinary Microbiology, 162(2): 793-799. DOI: https://www.doi.org/10.1016/j.vetmic.2012.10.015

Das A, Guha C, Biswas U, Jana PS, Chatterjee A, and Samanta I (2017). Detection of emerging antibiotic resistance in bacteria isolated from subclinical mastitis in cattle in West Bengal. Veterinary World, 10(5): 517-520. DOI: https://www.doi.org/10.14202/vetworld.2017.517-520

Diab M, Hamze M, Bonnet R, Saras E, Madec JY, and Haenni M (2017). OXA-48 and CTX-M-15 extended-spectrum beta-lactamases in raw milk in Lebanon: Epidemic spread of dominant Klebsiella pneumoniae clones. Journal of Medical Microbiology, 66(11): 1688-1691. DOI: https://www.doi.org/10.1099/jmm.0.000620

Diagbouga S, Salah FD, Sadji AY, Dabire AM, Nadembega Kere AB, Soubeiga ST, Ouattara AK, Zohoncon T, Belemgnegre M, Karou S et al. (2016). Detection of high prevalence of TEM/SHV/CTX-M Genes in ESBL Producing and multidrug resistant Klebsiella pneumoniae and Klebsiella oxytoca. JBR Journal of Clinical Diagnosis and Research, 4(1): 1-7. DOI: https://www.doi.org/10.4172/2376-0311.1000129

Dilhari A, Sampath A, Gunasekara C, Fernando N, Weerasekara D, Sissons C, McBain A, and Weerasekera M (2017). Evaluation of the impact of six different DNA extraction methods for the representation of the microbial community associated with human chronic wound infections using a gel-based DNA profiling method. AMB Express, 7(1): Article number: 179. DOI: https://www.doi.org/10.1186/s13568-017-0477-z

Economou V, and Gousia P (2015). Agriculture and food animals as a source of antimicrobial-resistant bacteria. Infection and Drug Resistance, 8: 4961. DOI: https://www.doi.org/10.2147/IDR.S55778

Gelasakis AI, Angelidis AS, Giannakou R, Filioussis G, Kalamaki MS, and Arsenos G (2016). Bacterial subclinical mastitis and its effect on milk yield in low-input dairy goat herds. Journal of Dairy Science, 99(5): 3698-3708. DOI: https://www.doi.org/10.3168/jds.2015-10694

Hijazi SM, Fawzi MA, Ali FM, and Abd El Galil KH (2016). Prevalence and characterization of extended-spectrum beta-lactamases producing Enterobacteriaceae in healthy children and associated risk factors. Annals of Clinical Microbiology and Antimicrobials, 15(1): Article number:3. DOI: https://www.doi.org/10.1186/s12941-016-0121-9

Hwang AY, and Gums JG (2016). The emergence and evolution of antimicrobial resistance: Impact on a global scale. Bioorganic and Medicinal Chemistry, 24(24): 6440-6445. DOI: https://www.doi.org/10.1016/j.bmc.2016.04.027

Kim Y, Choi E, Son B, Seo E, Lee E, Ryu J, Ha G, Kim J, Kwon M, Nam J et al. (2012). Effects of storage buffer and temperature on the integrity of human DNA. Korean Journal of Clinical Laboratory Science, 44(1): 24-30. Available at https://www.koreascience.or.kr/article/JAKO201203337761724.pdf

Kraker MEA, de Stewardson AJ, and Harbarth S (2016). Will 10 Million People Die a Year due to Antimicrobial Resistance by 2050? PLOS Medicine, 13(11): e1002184. DOI: https://www.doi.org/10.1371/journal.pmed.1002184

Li XZ, Mehrotra M, Ghimire S, and Adewoye L (2007). $\beta$-Lactam resistance and $\beta$-lactamases in bacteria of animal origin. Veterinary Microbiology, 121: 197-214. DOI: https://www.doi.org/10.1016/j.vetmic.2007.01.015

Lu Z, Sessler F, Holroyd N, Hahnel S, Quack T, Berriman M, and Grevelding CG (2017). A gene expression atlas of adult Schistosoma mansoni and their gonads. Scientific Data, 4(1): Article number:170118. DOI: https://www.doi.org/10.1038/sdata.2017.118

Mahlangu P, Maina N, and Kagira J (2018). Prevalence, risk factors, and antibiogram of bacteria isolated from milk of goats with subclinical mastitis in Thika East Subcounty, Kenya. Journal of Veterinary Medicine, pp. 1-8. DOI: https://www.doi.org/10.1155/2018/3801479

Maina D, Revathi G, and Whitelaw AC (2017). Molecular characterization of multidrug-resistant Klebsiella pneumoniae and Escherichia coli harbouring extended spectrum beta-lactamases and carbapenemases genes at a tertiary hospital, Kenya. Microbiologia Medica, 32(4): 132-137. DOI: https://www.doi.org/10.4081/mm.2017.7076

Mitema ES, Kikuvi GM, Wegener HC, and Stohr K (2002). An assessment of antimicrobial consumption in food producing animals in Kenya: Antimicrobial consumption in food producing animals. Journal of Veterinary Pharmacology and Therapeutics, 24(6): 385-390. DOI: https://www.doi.org/10.1046/j.1365-2885.2001.00360.x

Monstein H, Ostholm-Balkhed A, Nilsson MV, Nilsson M, Dornbusch K, and Nilsson LE (2007). Multiplex PCR amplification assay for the detection of blaSHV, bla TEM and bla CTX-M genes in Enterobacteriacea. APMIS, 115(12): 1400-1408. DOI: https://www.doi.org/10.1111/j.1600$\underline{0463.2007 .00722 . \mathrm{x}}$

Mshana SE, Hain T, Domann E, Lyamuya EF, Chakraborty T, and Imirzalioglu C (2013). Predominance of Klebsiella pneumoniaeST14 carrying CTX-M-15 causing neonatal sepsis in Tanzania. BMC Infectious Diseases, 13(1): Article number: $466 . \quad$ DOI: https://www.doi.org/10.1186/1471-2334-13-466

Naval Research Laboratory (NRL) (2017). High prevalence of antibiotic resistance in Kenya. ScienceDaily. Available at: https://www.sciencedaily.com/releases/2017/07/170711121501.htm

Ntirenganya C, Muvunyi CM, Manzi O, and Ogbuagu O (2015). High prevalence of antimicrobial resistance among common bacterial isolates in a tertiary healthcare facility in Rwanda. The American Journal of Tropical Medicine and Hygiene, 92(4): 865-870. DOI: https://www.doi.org/10.4269/ajtmh.14-0607

Okoko IM, Maina N, Kiboi D, and Kagira J (2020). $\beta$-lactam resistance in bacteria associated with subclinical mastitis in goats in Thika Subcounty, Kenya. Veterinary World, 13(7): 1448-1456. DOI: https://www.doi.org/10.14202/vetworld.2020.1448-1456

Oliver SP, and Murinda SE (2012). Antimicrobial resistance of mastitis pathogens. Veterinary Clinics of North America: Food Animal Practice, 28(2): 165-185. DOI: $\underline{\text { https://www.doi.org/10.1016/j.cvfa.2012.03.005 }}$ 
Rainard P, Foucras G, Fitzgerald JR, Watts JL, Koop G, and Middleton JR (2018). Knowledge gaps and research priorities in Staphylococcus aureus mastitis control. Transboundary and Emerging Diseases, 65: 149-165. DOI: https://www.doi.org/10.1111/tbed.12698

Raut S, Gokhale S, and Adhikari B (2015). Prevalence of extended spectrum beta-lactamases among Escherichia coli and Klebsiella spp isolates in Manipal Teaching Hospital, Pokhara, Nepal. Journal of Microbiology and Infectious Diseases, 5(2): 69-75. DOI: https://www.doi.org/10.5799/ahinjs.02.2015.02.0179

Raziq AH, Sulaiman AM, Merza NS, and Abdullah ZH (2017). Molecular detection of methicillin resistant Staphylococcus aureus harbouring $\beta$ lactamase resistance genes isolated from different sources of infections. Zanco Journal of Medical Sciences, 21(3): 1889-1896. DOI: https://www.doi.org/10.15218/zjms.2017.048

Ribeiro PCS, Monteiro AS, Marques SG, Monteiro SG, Monteiro-Neto V, Coqueiro MMM, Marques ACG, de Jesus Gomes Turri R, Santos SG, and Bomfim MRQ (2016). Phenotypic and molecular detection of the blaKPC gene in clinical isolates from inpatients at hospitals in São Luis, MA, Brazil. BMC Infectious Diseases, 16(1): 1-16. DOI: https://www.doi.org/10.1186/s12879-016-2072-3

Saisi H, Makobe C, Kangongo M, and Kariuki S (2019). Prevalence of CTX-M, SHV, TEM and OXA Genes among Extended-Spectrum BetaLactamase producing Klebsiella pneumoniae from Mukuru Slum, Kenya. Advances in Microbiology, 9(10): 853-862. DOI: https://www.doi.org/10.4236/aim.2019.910052

Sangare SA, Rondinaud E, Maataoui N, Maiga AI, Guindo I, Maiga A, Camara N, Dicko OA, Dao S, Diallo S et al. (2017). Very high prevalence of extended-spectrum beta-lactamase-producing Enterobacteriaceae in bacteriemic patients hospitalized in teaching hospitals in Bamako, Mali. PLoS One, 12(2): e0172652. DOI: https://www.doi.org/10.1371/journal.pone.0172652

Scarafile G (2016). Antibiotic resistance: Current issues and future strategies. Reviews in Health Care, 7(1): 3-16. DOI: https://www.doi.org/10.7175/rhc.v7i1.1226

Shah AA, Hasan F, Ahmed S, and Hameed A (2004). Characteristics, epidemiology and clinical importance of emerging strains of Gram-negative bacilli producing extended-spectrum $\quad \beta$-lactamases. Research in Microbiology, 155(6): 409-421. DOI: https://www.doi.org/10.1016/j.resmic.2004.02.009

Shahid M, Singh A, Sobia F, Rashid M, Malik A, Shukla I, and Khan HM (2011). blaCTX-M, blaTEM, and blaSHV in Enterobacteriaceae from North-Indian tertiary hospital: High occurrence of combination genes. Asian Pacific Journal of Tropical Medicine, 4(2): 101-105. DOI: https://www.doi.org/10.1016/S1995-7645(11)60046-1

Shaikh S, Fatima J, Shakil S, Rizvi S, Mohd D, and Kamal MA (2015). Antibiotic resistance and extended spectrum beta-lactamases: Types, epidemiology and treatment. Saudi Journal of Biological Sciences, 22(1): 90-101. DOI: https://www.doi.org/10.1016/j.sjbs.2014.08.002

Su Y, Yu CY, Tsai Y, Wang SH, Lee C, and Chu C (2016). Fluoroquinolone-resistant and extended-spectrum $\beta$-lactamase-producing Escherichia coli from the milk of cows with clinical mastitis in Southern Taiwan. Journal of Microbiology, Immunology and Infection, 49(6): 892-901. DOI: https://www.doi.org/10.1016/j.jmii.2014.10.003

Tadesse BT, Ashley EA, Ongarello S, Havumaki J, Wijegoonewardena M, González IJ, and Dittrich S (2017). Antimicrobial resistance in Africa: A systematic review. BMC Infectious Diseases, 17(1): Article number: 616. DOI: https://www.doi.org/10.1186/s12879-017-2713-1

Ur Rahman S, Ali T, Ali I, Khan NA, Han B, and Gao J (2018). The growing genetic and functional diversity of extended spectrum beta-lactamases. BioMed Research International. Pp. 1-14. DOI: https://www.doi.org/10.1155/2018/9519718

Younis G, Awad A, and Ashraf N (2017). Molecular and phenotypic characterization of antimicrobial resistance in gram negative bacteria recovered from subclinical mastitis. Advances in Animal and Veterinary Sciences, 5(5): 196-204. https://www.doi.org/10.17582/journal.aavs/2017/5.5.196.204

Zaniani FR, Meshkat Z, Naderi Nasab M, Khaje-Karamadini M, Ghazvini K, Rezaee A, Esmaily H, Nabavinia MS, and Darban Hoseini M (2012). The prevalence of TEM and SHV genes among extended-spectrum beta-lactamases producing Escherichia coli and Klebsiella pneumoniae. Iranian Journal of Basic Medical Sciences, 15(1): 654-660. Available at: https://www.ncbi.nlm.nih.gov/pmc/articles/PMC3586863/ 